\title{
Using Active Engagement Strategy to Promote Learning Awareness and Self-Monitoring
}

\author{
Ang Chooi Kean \\ International Languages Dept., Institute of Teacher Education International Languages \\ Campus \\ Lembah Pantai, 59200 Kuala Lumpur \\ Tel: +603-22847652Ｅ-mail: ackean05@gmail.com \\ Mohamed Amin Embi (Corresponding author) \\ Centre for Academic Advancement, Universiti Kebangsaan Malaysia \\ 43600 Bangi, Selangor, Malaysia \\ Tel: +603-89215969 E-mail: m.amin@ukm.my
}

Received: September 17, 2011 Accepted: October 27, 2011 Published: November 22, 2011

Doi:10.5296/ijld.v1i1.1105 URL: http://dx.doi.org/10.5296/ijld.v1i1.1105

\begin{abstract}
This paper reports an ongoing practice attempting to promote learning awareness and self-monitoring in a Japanese language oral communication classroom of a 12-Week Preparatory Course under the local in-service teachers' Japanese language teacher training programme. It aims to share the experiences and challenges faced in planning and implementation of the practice. In providing a mid-term review on the effort taken, an online questionnaire was administered to the 15 course participants. The results of the questionnaire obtained from 14 respondents, together with reflection reports submitted by 3 selected participants were examined to find out the influence of the practice onto their learning and perceptions among the participants towards the practice within the first half of the course of 6 weeks. The initial findings showed positive results in the aspect of learning awareness in all participants. However, there were only a few cases with indication in the aspect of self-monitoring.
\end{abstract}


Keywords: active engagement, learning awareness, self-monitoring, Japanese language, oral communication, teacher training

\section{Background}

In line with the Ministry of Education's internationalization programme, International Languages Teacher Training Institute (IPBA, then; now, Institute of Teacher Education International Languages Campus: IPG KBA), under the Teacher Education Division of Ministry of Education was given the mandate to train skilled and qualified teachers of international languages in order to meet the demand of the teachers in secondary schools. Japanese language in-service teacher training programme began in 2005. In September 2005, a 12-Week Preparatory Japanese Language Course was started and this was followed up with the One Year Teaching of Japanese as a Foreign Language Course (TJFL). Upon successful completion of the one year and three months courses in IPBA, the "converted" teachers are reposted to both day schools and fully residential schools offering Japanese language subject. During their first year as the newly qualified Japanese language teachers, the teachers are required to undergo an internship programme whereby they are being called back to IPG KBA to attend a 3-day short course twice and also an Action Research Seminar (either as presenter or participants). In their second year as Japanese language teachers, the teachers would then proceed on to an immersion course at The Japan Foundation Japanese Language Institute, Urawa through participating in their 2-month short-term teacher training programme there in Japan.

\section{Objective of the Study}

In spite of the intensiveness and concentration of the programme on language competency with a total credit hours of 840 hours (12-Week Course: 300 hours and 1 Year Course; 540 hours ${ }^{1}$ ), oral communicative competency remains a major issue. (JFKL, 2010). In other words, the level of proficiency of most course participants at the end of the programme remained to be at a lower intermediate level. Based on the researcher's observation and final reports throughout the first circle of a 5-year implementation (IPG KBA, Annual Reports of TJFL Course, 2006-2010) the reasons could be divided into two main problematic categories. The first category involves the choice of instructional materials in the programme (especially in the 12-Week Preparatory Course) and the second category concerns with instructional methods which might have resulted in the lack of "real learning" throughout the programme. This paper examines the effort and initiative of the researcher as the instructor in-charge of speaking skills in overcoming the latter category.

This paper reports on the use of active engagement strategies in oral classroom to promote learning awareness and self-monitoring skills among the learners in the current 12-Week Preparatory Course which began in mid-August 2011.

In short, this paper aims to examine the influences of the pratice from learners' perceptions on the practice. It also attempts to discuss the considerations in developing classroom

\footnotetext{
${ }^{1}$ Currently (September, 2011) the One Year Course is being reviewed and thus the credit hours are subjected to change.
} 
materials and challenges faced by the instructor in providing better facilitation and more conducive learning environment.

\section{What is Active Engagement?}

According to Lorain (n.d.), when students are actively engaged in their learning, they are processing and retaining information and using higher order thinking. When teachers design activities that promote active engagement, they are reinforcing student learning, keeping students interested and on task, and making learning relevant and fun. Therefore, effective teachers will capitalize on their students being young adolescents want to do things and will do things to reinforce their students' learning.

In other words, teaching that emphasizes active engagement helps students process and retain information. It leads to self-questioning, deeper thinking, and problem solving. Engagement strategies like repetition, trial and error, and posing questions move the brain into active and constructive learning. And such activities can lead to higher student achievement. This view is also shared by Bonnycastle(2008), a writer in the Medical Education in her writings about Active Engagement. She wrote that students need to be actively involved mentally and/or physically in learning in order to move through the learning cycle. She further illustrated that out of every 100 items in a passive lecture, students will remember approximately 10 and if one took the same amount of time to actively involve students, he or she might only cover 75 items, but students would remember approximately 15, also those 15 items are more likely to be linked storage that can be retrieved more effectively in the future.

\subsection{Challenges in Active Engagement Strategy}

Preparing classes that actively engage students requires a lot of planning. First, the teacher must prepare the lecture or other type of instruction. Then, he or she must select learning activities that support the content of the instruction and engage students. Lorain (n.d.) outlines five steps that teachers should follow: (1) Thoroughly learn/understand the curriculum, (2) Identify teaching objectives and strategies that engage students and build understanding, (3) Ask oneself these planning questions: (i) What is the goal? (ii) What order does the teaching need to follow? (iii) What do the students already know? (iv) What do I want them to learn? (v) Prepare the lecture or instruction of the concepts and skills, based on the goals. (vi) Construct processing/learning activities that match the concepts, skills, and goals.

In addition, to engage students, the teacher must do more than lecture. While teaching the concepts and skills, the teacher must help students draw on their own experiences to build a "scaffold" on which they can "hang" new ideas. When students are actively engaged, they focus on what is being taught and better process new information.

\subsection{Considerations in Active Engagement Strategy}

Lorain (n.d.) noted that the most effective teaching takes place in "chunks," and advised that it is best to teach new information or concepts in 7-to-10-minute segments followed by a processing activity. In short, after teaching several segments, the teacher can use a longer 
processing activity. This activity should be tied tightly to the concepts or skills previously taught so that it builds understanding.

\subsection{Importance of Processing Activities in Real Learning}

In ensuring real learning (namely the acquisition of the targeted language skills) to take place, internalization of the learning is important. Students have to be supported and given ample opportunity to internalize the learning content in the learning process. This could be done through processing activities. A processing activity is an activity that causes students to pose questions, manipulate information, and relate the new learning to what they already know. Such engagements reinforce the learning and help move the learning to the long-term memory banks. A processing activity can be as simple as a 60-second jotting down of the important points just covered, telling a partner three things that he or she has just learned, or writing down the answer to an open-ended question ("One-minute paper") in order to check the level of concept formation in the class, or writing down the muddiest point that he or she has trouble understanding ("Muddiest Point") and handing it in at the end of the class. Some examples of longer processing activities are: (1) Designing a concept or site map, (2) Creating an outline or flow chart, (3) Producing short videos that demonstrate learning points.

Olson (n.d.) listed down 6 components of explicit instruction of Active Engagement strategies which include: (1) Setting the Stage, (2) Explaining to Students What to Do, (3) Model for Students What to Do, (4) Guided Practice, (5) Independent Practice and (6) Closure/Assessment. This list displays a development of a learning process from the initial stage of introducing the learning goals until the assessment of the achieved goals.

\section{Methodology}

This study is an exploratory study which employed both quantitative and qualitative data. The subjects of the study are the 15 participants (6 males and 9 females) of the Cohort 6 undergoing the12-Week Preparatory Japanese Language course. However, there were only 14 respondents in this study as one participant failed to submit the questionnaire.

In this study, data collection was administered using an online questionnaire survey. The questionnaire comprised three sectional 44 quantitative data based items and an open-ended item. In addition, qualitative data from selected reflection reports examination was also used to support and supplement the data collection in identifying the elements of learning awareness and self-monitoring.

The online questionnaire survey was administered after the first half of the course (a duration of six weeks) and the reflection reports from 3 selected participants which were submitted on the seventh week of the course were examined for the purpose of triangulation.

\section{Data Analysis and Findings}

The quantitative data collected from the questionnaire was analyzed based on the 3 sections pertaining to the 3 main active engagement strategies employed throughout the six weeks of the course. They were (1) Speaking Journal, (2) Role Play Video Creation and (3) Learner-centred based Classroom Activities. The qualitative data from the comments and 
suggestions in the questionnaire and selected reflection reports were examined and analyzed based on the Grounded Theory of categorization.

Findings were discussed according to the types of data in the following paragraphs below.

\subsection{Quantitative Data}

The data derived from the perception questionnaire contains 15 statements each for the first two sections on "Speaking Journal" and "Role Play video creation" and 14 statements for the section on "Classroom Activities" mentioned earlier. The type of data analysis for the quantitative data adopted was analysis of the data obtained on a 5-point Likert scale, ranging from "Strongly disagree (1)" to "Strongly agree (5)" Likert-scale.

All respondents perceived that the active engagement activities employed had helped them in self-directed learning as they could analyze problems on their own, changed their approach to learning and also changed the way they think when encountering learning problems. All respondents had also agreed that the activities were impactful in promoting learning awareness and self-monitoring up to a certain degree which varied according to the three main types of activities.

Table 1: Total Agreement on Statements pertaining to "Speaking Journal"

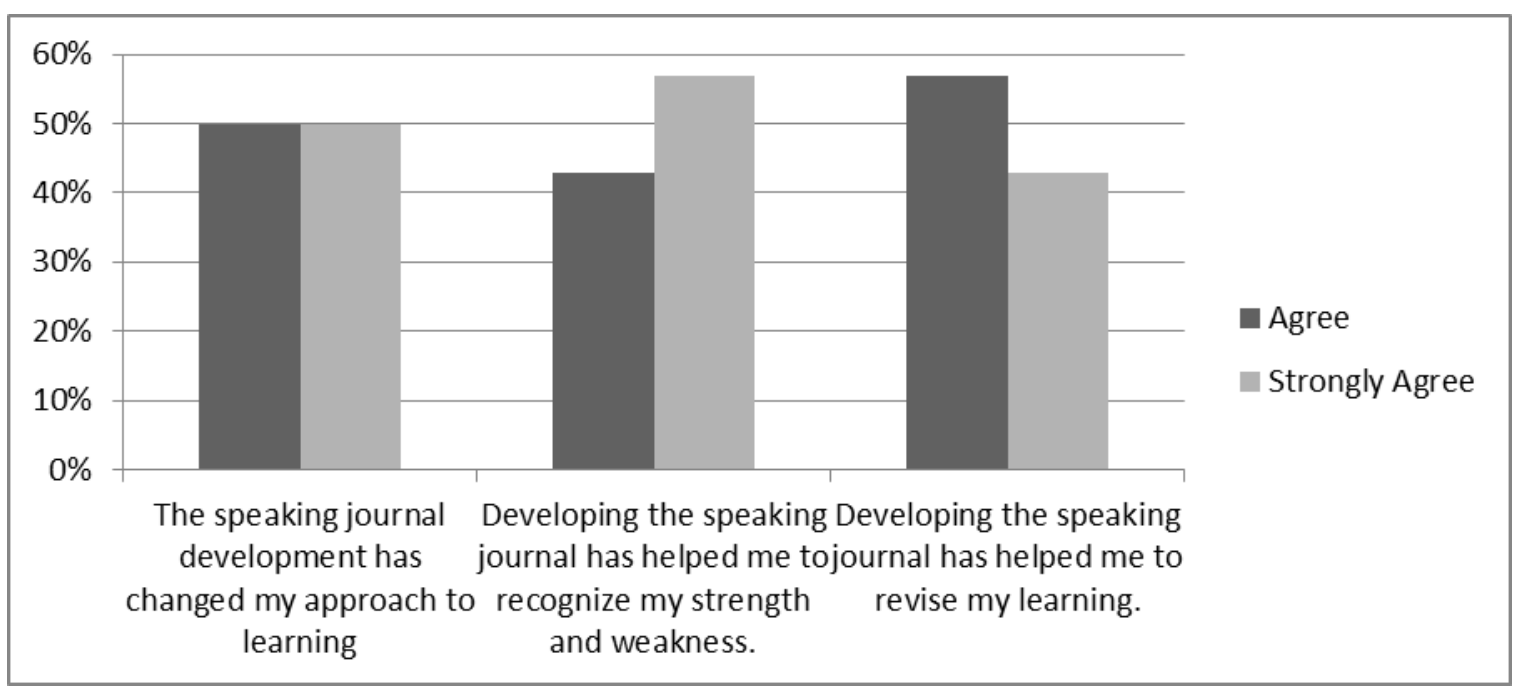

Table 1 above displays the findings result pertaining to the total agreement on statements about "Speaking Journal". All respondents (100\%) agreed that the "Speaking Journal' had changed their approach to learning helped them to recognize their strength and weakness and helped them to revise their learning. 
Table 2: Total Agreement on Statement pertaining to Role Play Video Creation

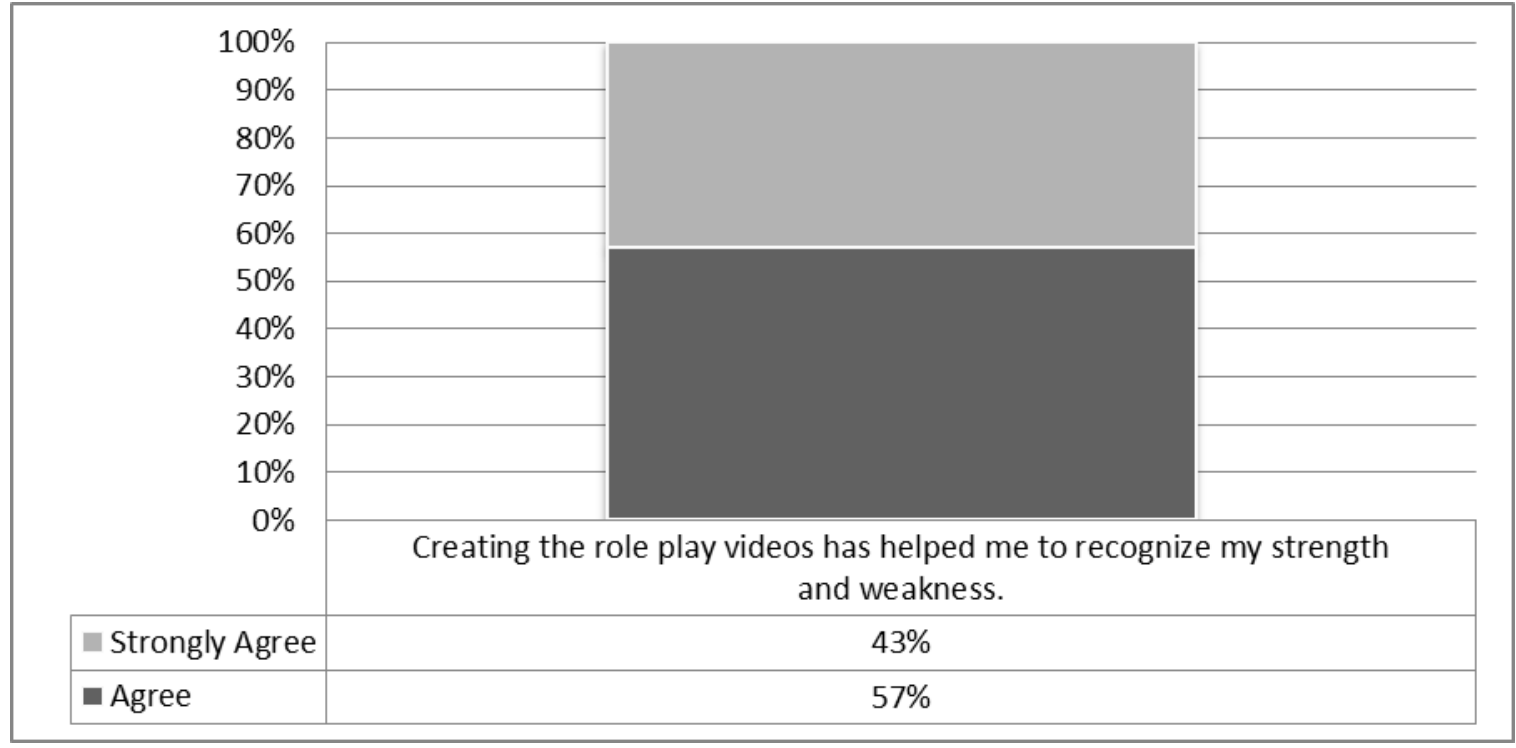

Table 2 above shows that all respondents claimed that the role play video creation had helped them in recognizing their own strengths and weaknesses.

Table 3: Total Agreement on Statements pertaining to Classroom Activities

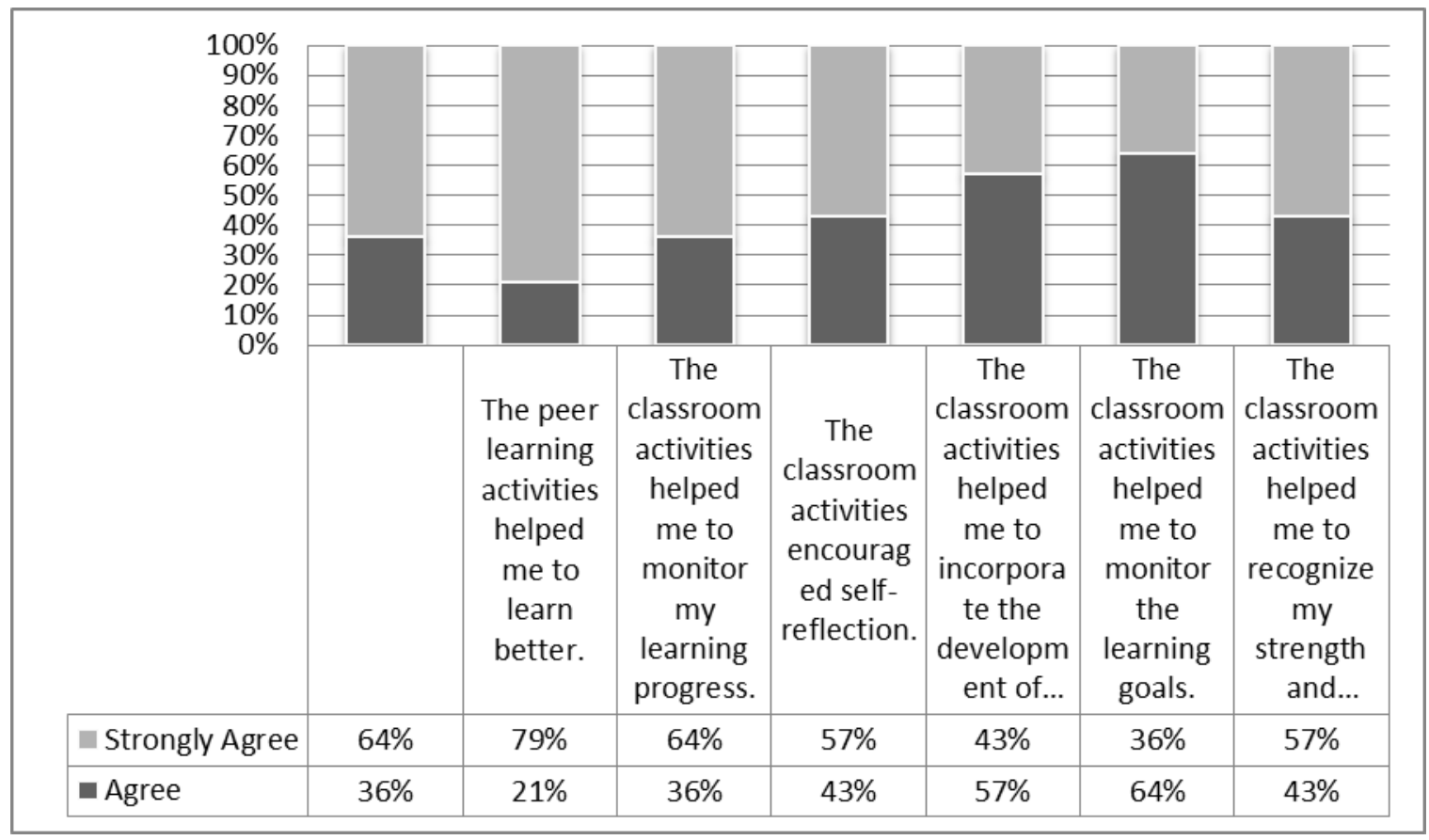

In comparison, "Classroom activities" recorded more items with 100\% agreement among the respondents in which they claimed that the activities had helped them developed basic understanding in their learning items, always incorporated peer learning, helped them to 
learn better, helped them to monitor their learning progress, encouraged reflection, helped them to incorporate the development of their learning, helped them to monitor their learning goals and helped them to recognize their strengths and weaknesses.

Majority of the participants claimed that they had enjoy the activities In addition, 93\% agreed that the classroom activities were engaging and interactive. On the other hands, $7 \%$ (1 participant) did not enjoy the Speaking Journal. Similarly, 7\% (1 participant) did not enjoy Role Play Creation and 7\% (1 participant) seemed to be neutral pertaining to enjoying the classroom activities.

In regard to the influences on their learning outcomes, 13 out of 14 respondents (93\%) indicated that the "Speaking Journal" had helped them to improve their speaking skill. A total of 11 out of 14 respondents (79\%) appreciated that their communication skills had improved through the "Role Play Video Creation" and 12 out of 14 respondents (86\%) agreed that the classroom activities had improved their communication skills.

Although the respondents were relatively positive about the activities, 2 respondents (14\%) found the "Speaking Journal" to be stressful and 4 respondents $(28 \%)$ claimed that creating "Role Play" was stressful. Nevertheless, as mentioned earlier, all respondents agreed that "Speaking Journal" development had indeed changed their approach their approach to learning, and12 respondents agreed (with the other 2 respondents remained neutral) that the "Role Play Video Creation" had changed their learning approach to learning and the way they think when they encounter problems in their learning. Almost all participants ("Speaking Journal": 13 (93\%) agreed and 1 (7\%) neutral;. "Role Play Video Creation": 12 (86\%) agreed and 2 (14\%) neutral; "Classroom activities": 12 (86\%) agreed and 2 (14\%) neutral) also perceived that the three activities had given them insight into outcome-based learning and that they used resources other than textbooks to develop the learning issue.

In addition, all participants claimed that the "Speaking Journal" had helped them to revise their work. Similarly, almost all participants (93\%) agreed that the "Role Play Video Creation" and $86 \%$ of the participants agreed that the "Classroom activities" had helped them to revise their work. Among the respondents, 9 (64\%) indicated that in performing the three activities, they had used resources other than was taught in class to develop the learning points. All respondents (except for 1 participant who remained neutral) felt that they were provided adequate guidance in all the activities.

\subsection{Qualitative Data}

In this study, the qualitative data consisted of the open-ended item in the questionnaire and the 3 selected reflection reports. 


\subsubsection{Open-ended item}

The qualitative data obtained from the open-ended item provided clearer and more information as well as insights into the feelings of the respondents, and their perceptions, their opinions and beliefs of their learning experiences from the 3 types of activities.

Ten categories were formulated from the data analysis based on Grounded Theory. They are "Sense of Enjoyment", "Sense of Appreciation", "Sense of Achievement", "Learning Awareness", "Determination/Self-Realization", "Monitoring", "Time Related Concerns", "Self and Others' Expectation", "Problem and Hindrance" and "Suggestion".

Generally the findings confirmed positive perceptions about the strategies employed. There were indications of raising learning awareness among the participants. An exemplary excerpt was as follows:

...I need to read, record my own voice, and re-listened it to increase self confidence at my speaking skills.

Another insightful excerpt was:

...may get confused at time when sensei was explaining but after a role play or activity, I normally can get a deeper insight and understanding of the topic. I am able to add more vocabulary to the list.

The above response indicated that the participant's raising awareness about "actual learning" which is not about receiving explanation from the teacher about the topic but rather through actual use of the information in an activity whereby during that process, the learner gained insights and developed understanding of the topic and in turn, this would lead to increased use of vocabulary.

Nevertheless, the findings also brought into light that the main hindrance felt was the time constraint due to the short duration of the course and other activities, the volume of content and some "resistance" or "reservation" felt towards the lacked of "spoon-feeding" or "teacher-centredness" method particularly in the provision of all information (namely vocabulary list) needed and dependence on written form of supports (namely reading) during the oral learning process. In other words, the teacher-centred learning style preference or "old learning habit " of some learners is an issue and may pose a big challenge in the success of the practice. Interestingly, there was always also a response which aptly identified the possibility of this particular challenge. In addition, "self-expectation or others' expectation" also indicated that some participants might feel pressurized which in time might lead to either positive or negative consequences. The former would be in enhancing their motivation to live up to the expectation felt but the latter would be the exact opposite direction which might be feeling disheartened and frustrated with oneself or others.

Another interesting findings was noted in the response about the appreciation of the effective use of ICT in promoting the learning and self-directedness among the participants. However, 
it must also be noted that there was a particular comment about the limitation of internet connectivity or availability of internet access which rather negated the effective use of the ICT.

\subsubsection{Reflection Report}

As mentioned earlier, selected reflection reports were examined to enable the researcher to further discover and specifically identify the actual practice and degree of the influence of the practice in promoting learning awareness and self-monitoring among the course participants.

In regard to indication of learning awareness, an exemplary entry on the realization and appreciation of applying the learning based on student-centred approach The statement written was:

In the speaking class, I learnt names of places and prices. I enjoyed the session very

much. In my opinion, Sensei has managed to use a very effective student-centred approach for us to apply what was taught. I felt fortunate to be able to be in a classroom where theory is being transferred successfully into practice.

-Excerpt from a $6^{\text {th }}$ Week Reflection by Participant $A$

Another example also indicated the respondent's awareness and sense of achievement pertaining to application of meaningful contextualized learning. Her reflection on authentic assessment and evaluation statement quoted was:

.....Ifeel the sense of satisfaction in sensei's class. I experienced this when I able to apply the learning into meaningful practice at the end of the lesson. I realized that I able to reply to questions quite fast even though there might be mistakes here and there.

-Excerpt from a $7^{\text {th }}$ Week Reflection by Participant $B$

In addition, there was also an exemplary entry which indicated self-assessment on her learning process:

I personally think that your class is very meaningful and informative. Your style of making it visible through context is very effective. Every time after your class, I will be able to speak a bit more than before. I can also learn new words or phrases.

This teaching approach is very encouraging.

-Excerpt from the $6^{\text {th }}$ Week Feedback Reflection by Participant $C$

In the case of development of self-monitoring skills, very few explicit examples were found. Below excerpt encapsulated the indication of the element of self-monitoring:

Secretly, ...sensei's class is the most tensed because we have to speak. She also has a wide range of vocabulary that seems to be able to 'bombard' our tiny brains.

But, despite the stress, I do have to admit that I learn a lot from the class. The teaching is more and more effective. I can understand more even when Ang sensei is using Japanese. Her gestures gives us the hints. This trains my inferencing skill which 
I still have lots of rooms to improve on.

-Excerpt from the $7^{\text {th }}$ Week Reflection by Participant $C$

2011, Vol. 1, No. 1

\section{Implication and Discussion}

In this session, considerations and challenges faced in the planning and implementing the practice were discussed along with the discussions on implication of the study.

\subsection{From Teacher-Centredness to Learner-centredness}

In general, the findings indicated the active engagement activities had significant influences on the participants in terms of their learning awareness and to a certain degree, toward development of their self-monitoring skills. In short, in applying active engagement strategy, all participants were involved or rather "made to be involved" in their learning process. Hence, the results of the findings which indicated as such. In a nutshell, active engagement activities emphasized the element of learner-centredness in them.

Learner-centredness is often examined based on learner involvement in the learning process and focused on development of student awareness and preparedness for learning. Nunan and Lamb (1996) viewed learner-centredness as active learners' involvement in their own learning processes. Nunan and Lamb also emphasized that "in an ideal learning-centred context, not only will decisions about what to learn and how to learn be made with reference to the learners, but the learners themselves will be involved in the decision-making process.

This study showed that the respondents in "actively practising the use of language items introduced" were indeed involved in their learning processes especially in the decision-making process in relation to what and how to use in the contextualized activities, how to learn better through self-reflection or rather "internalization" of the language items and functions and so on. This was in tune with Meltzer (2002) who noted in his experiment with active engagement strategy, "they (the students) are exposed to fewer topics than in a traditional class, but seem to learn the concepts they study in much greater depth." (p.2).

In planning the activities, the researcher was mindful of the learning objectives to be reworded in "Can-do-statements" (CDS) which displayed learning outcomes from the learners' perspectives. This is crucial in allowing the learners to be aware and take note of their learning goals. In planning of time allocation, considerations of more time on practice to be allocated in the practice rather than the input by the teacher. At the initial stage of the lesson (or series of lessons), only basic vocabulary and language forms were introduced and further developed according to the "necessities" for the use of other related vocabulary and language forms felt by the learners in their "real use" during the activities. To facilitate this to happen, it is important to develop a range of the contexts of the real use of the language items and forms from a simple to complex manner. Variations and different choices of use need to be also considered and introduced. In doing this, one challenging demand that would be faced by the teacher would be the art of facilitation and the skills in handling different types 
and learning speed of the learners. As shown by the findings of this study, the amount of vocabulary and learning items were perceived differently by the participants. As indicated by the findings, there were some who felt that the amount was too much for them to handle within the short period of time. This could be avoided if the learners were made to be more aware of the minimum level of their learning to be achieved according to their capabilities to consume the information made available during the classes. However, as noted earlier, the "spoon-feeding" or "teacher-centred" learning they were accustomed to, posed an hindrance to this new method of learning in which they need to be "selective" and "self-monitor' their own learning accordingly. Another notable consideration was the preparation of notes pertaining to vocabulary and language forms. However, the notes were only distributed at the end of a topic in order to provide an overall summary and checklist to the participants.

Similarly, this study brought to light, the varied perceptions among the participants. Again, some preferred to be provided the notes at the beginning of the topic in order to provide them ready-guidance and references for them to revise the lessons. On the other hands, those who appreciated the nature of the notes which provide them a platform to "digest" and "think" about the learning items would "understand" the rationale of the notes being distributed at the end of the lessons or a particular topic. The point of argument here would be that some participants lacked the initiative or effort in taking down notes at the end of each lesson on their own and hence their preference for ready notes to be made available by the teacher. This phenomenon implies that note-taking practice or rather note-taking skill should be taken into consideration in ensuring all participants take the trouble to note down their learning constantly at the end of each day or week throughout the duration of the course. A specific appropriate strategy would be keeping a learning log. This effort is important in promoting self-directed learning among the participants during and beyond the course.

The findings revealed that the practice has indeed indirectly molded the participants (even though not totally but to a certain degree) into independent learners as their awareness in relation to their learning process was being enhanced. Mariani (1992) said that an independent learner uses effective strategies; has appropriate knowledge and holds positive beliefs and attitudes and that these three different areas are very much interrelated. Mariani noted that part of training learners for independence actually consists in raising the awareness of these factors. In short, basically, they as independent learners know how to make the most of their cognitive processes. In this course, the researcher took the effort to facilitate the participants in providing the "know-how" in comprehending the information, and using elaboration strategies like flow charts and illustrations.

In addition to cognitive strategies, independent learners use metacognitive strategies, that is, they know how to plan, monitor and evaluate their language learning (Mariani, 1992). However, the findings revealed that metacognitive strategies among the participants were still not fully developed as yet and hence, the self-monitoring skills among the participants were still insignificant at this point of the study. The probable reason would be the short duration of this study as metacognitive strategies need longer time to be developed. 


\subsection{Readiness of the Participants As Learners}

Another important factor to consider is the "beliefs and attitudes" that participants hold. As pointed out by Mariani (1992), general ideas about language and learning tum into very specific beliefs and attitudes within each individual learner. In other words, what learners know about language and learning, they apply to their own personal situation as a language learner. Therefore, if the learner thinks that language is all about a set of rigid rules, they will react negatively to communicative activities which are perhaps high on fluency and low on accuracy; they will not be ready to take risks and tolerate ambiguity. If they think that memory is the most important factor in learning a language, and are convinced that they have a very bad memory, they will probably not be very confident in their language learning abilities. If they think that language learning is a process which is basically handled by the teacher, and if this is what has always happened to them at school and maybe as teachers (before joining the programme) they practiced as such too; they will resist the offer of self-directed learning or of a self-access method.

In short they will simply not be confident enough to believe in their own independence. As aptly said by Mariani (1992), learners' beliefs and attitudes are influenced by their previous learning experiences, particularly by the feelings of success or failure that they have experienced, by the roles that they have played at school, by the general "image" that they have of themselves as learners. However, counting on the fact that these beliefs and attitudes can be brought to consciousness: this is the reason why language and learning awareness becomes perhaps the single most important idea in training learners for independence. One of the most significant considerations taken in the practice was incorporating peer learning into the classroom activities and learning tasks. Through peer activities, the participants would be able to handle and overcome such "insecurities" or "reservation" toward independent learning. According to Tateoka (n.d.), peer learning is literally mutual learning from peers in which it is about learning how to learn and cooperate with each other to bring about the "power of learning" through the interaction. She further emphasized that the most important concept in peer learning is collaborating which is about helping each other out and doing creative work together. Nevertheless, a challenge faced by the researcher was matching the right "peer" among the participants and choosing and planning suitable types of peer learning activities and tasks without consuming too much time.

Another issue which was indicated by the findings of the study was the element of "judgment" by some participants from 'teachers' beliefs and perspectives. This was unavoidable as the participants in this course were all in-service teachers and some might possessed strong sets of beliefs and "successful" practices of their own, maybe especially so for those who were from non-language subjects such as examination-oriented subjects like Science and Mathematics.

\subsection{Application of ICT as Learning Platforms}

In developing the course, the researcher applied and adapted ICT tools such as multimedia power point presentation and utilized audio and video recordings made available by the mobile 
phone technologies. These efforts were deemed significant and importance in allowing the participants to optimize their out-of-classroom learning and in turn, develop their self-monitoring skills. In addition, sharing platforms for learning products should also be made available outside the classroom in order to maximize classroom time for adequate practices during classroom activities. In this course, the researcher created a classroom website provided by Google Site for this purpose. However, as the amount of learning products increased, the researcher faced problem due to the limitation of data storage available which was subsequently overcame by uploading of the video clips onto Youtube. This sharing platform which enabled mutual comments and subsequently, provides a platform for "behaviour management" among the participants in the practice of "sharing culture" as well as tackling their learning concerns or issues through observing "good practices" by other participants or receiving learning tips from their peers and teacher and so on. However, undeniably, such ability of a learner to self-monitor his or her performance is a natural step toward becoming independent, can only happen when students take responsibility for their own behavior and essentially become "agents of change" (Hanson, 1996; Porter, 2002; Rutherford Quinn, \& Mathur, 1996, as cited in Hoffman Kaser, n.d.). However, at this point of time, the findings in this study did not indicate clear element of self-monitoring that existed in the respondents as yet. This might be due to short duration of the study which was a mere 6 weeks. Nevertheless, learners must be taught to self-monitor and self-evaluate their success each day (Vaughn, Bos, \& Schumm, 2000 as cited in Hoffman Kaser, n.d.). In other words, to be successful self-monitors, students need to learn to keep track of what they are doing and how they are thinking so they can adjust their behaviors and thoughts in order to meet goals or complete tasks. In addition, to help maintain and generalize positive behavioral changes, self-monitoring should be combined with methods that allow students to evaluate themselves against their earlier performance and to reinforce themselves for their successes.

Another important efforts taken by the researcher in developing self-monitoring skills among the participants were immediate and constant feedbacks on the participants' learning products which were sent through email attachments almost every day at the initial stage of the course. Admittedly, it was tedious and time-consuming on the part of the instructor, but the "joy" and "thrills" felt by a teacher who could "see" the growth and the learning impacts experienced by the participants throughout the learning processes were indeed "gratifying" and worth the trouble.

On the other hands, this study has also clearly showed that time constraint felt by participants in the course posed as a main hindrance in the practice. In addition, as aptly pointed out by a respondent, "speaking class cannot stand by its own", in order to inculcate self-monitoring skills and self-directedness among the participants in the course, the researcher strongly suggests that all instructors involved in the training programme should rethink and review their current delivery methods of instructions in order to better integrate the four basic language skills. 


\section{Conclusions}

It is interesting to note that in this study, all respondents perceived that active engagement activities had indeed changed their perceptions toward their learning approach. Even though, some still seemed to be facing some sort of "inner struggles" as they perceived the activities (namely "Speaking Journal" and "Role Play Video Creation") to be stressful. The reason might be because such activities demanded more time and efforts in the thinking and creating and developing processes. Nevertheless, as argued by Ang and Mohamed Amin (2010), it is quite ironic to note that it is because of the intensive nature of the programme with regard to the training duration, it is indeed important and necessary to promote learner-centredness and inculcate self-directedness in the course participants in order to produce independent learners that would and could monitor their own learning during and even after the programme. Moreover, according to Mariani (1992), promoting learner independence is all about changes and all about choices. Training learners for independence is basically a willingness to change. Hence, Mariani noted that it is necessary to promote changes, not just in the learners, but in the teachers and in their working conditions, namely in their awareness, knowledge and skills in order to change the patterns of interaction in the classroom from teacher-centredness to learner-centredness; the learning tasks that they set in order to provide the learners with an awareness of language and of language learning and allow them the chance to plan, monitor and evaluate their performance and opportunities to make choices which includes, for example, a reassessment of the textbooks and materials that are in use and institutional constraints in order to identify all the possible ways to promote independence in teaching and learning conditions: for example, ways of managing class time and space in more flexible arrangements, ways of organizing self-access facilities at school or even in our own classroom; and ways of "reinventing" homework tasks, so that learners can make the most of their time out of school (as cited in Ang \& Mohamed Amin, 2010). Hence, the efforts in the facilitation of active engagement of the participants in their learning activities during this initial 12 Week Preparatory Course of the whole training programme is deemed to be significant and necessary towards promoting self-directedness among the participants.

In the remaining period of the course and its subsequent 1 Year course, experiential learning opportunities in real-life situations would be provided. There is no better way to understand peoples of other cultures or to learn their language than to be placed in real-life situations where communication must be negotiated face-to-face with native speakers of the targeted language. In such situations, students are not only actively involved in their own learning, but in many cases are solely responsible for this learning. According to Leonard (2002), research has shown that when cultural exchanges take place between diverse groups, increased interest and motivation figure prominently not only in the learning of a second language, but also in participants' continued interest in experiencing other cultures first hand, something foreign language educators continually strive to promote. As a Chinese proverb aptly has it, "Tell me and I forget. Show me and I will remember. Involve me and I will understand." 
In a nutshell, teachers need to shift their teacher-centred practice to a learner-centred practice. The importance of this shift of the role of teachers as provider of information to the roles of facilitator of learning and hence, inducer of self-directedness in learning is aptly summarized by the statement below:

Ideal teachers are those who use themselves as bridges over which they invite their students to cross, then having facilitated their crossing, joyfully collapse, encouraging them to create bridges of their own.

-Nikos Kazantzakis

\section{References}

Ang, C.K. \& Mohamed Amin Embi (2010). Promoting learning awareness and self-Monitoring through learning Portfolio development among Japanese Language learners. European Journal of Educational Studies 2(3), 2010. 293-304. http://ozelacademy.com/EJES_v2n3_12.pdf

Bonnycastle, Deirdre. (2008). Active Engagement. Medical Education. [Online] Available: http://medicaleducation.wetpaint.com/page/Active+Engagement (September 1, 2011).

Hoffman Kaser, C. (n.d.) Series on Highly Effective Practices-Self Monitoring [Online] Available: http://education.odu.edu/esse/docs/selfmonitoring.pdf (October 16, 2009).

Institut Pendidikan Guru Kampus Bahasa Antarabangsa (IPG KBA). Annual Reports of One Year Teaching of Japanese as a Foreign Language Course, 2006-2010.

Leonard, Kathy S. (2002). Learning Spanish through Experience. Teaching At ISU,

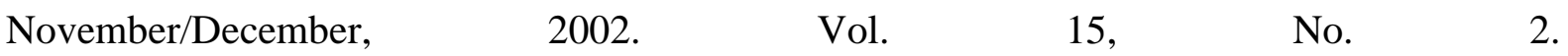
http://www.celt.iastate.edu/pdfs-docs/NewsletterPDFs/cte-v15n2.pdf

Lorain, Peter. (n.d.) Teaching That Emphasizes Active Engagement. Improving Learning for Middle School Students. [Online] Available: http://www.nea.org/tools/16708.htm (September 30, 2011).

Mariani, Luciano. (1992). Language awareness/learning awareness in a communicative approach: A key to learner independence Perspectives, a Joumal of TESOL-Italy Volume XVIII (2), December 1992. http://www.learningpaths.org/papers/paperawareness.htm.

Meltzer, David E. (2002). Using Active-Engagement Teaching Methods in Large-Enrollment Classes to Improve Student Learning. Teaching At ISU, November/December 2002. Vol. 15, No. 2. http://www.celt.iastate.edu/pdfs-docs/NewsletterPDFs/cte-v15n2.pdf

Nunan, David \& Lamb, Clarice. (1996). The self-directed teacher: Managing the learning process. Cambridge: Cambridge University Press. 
Olson, Cheryl. (n.d.) Active Engagement Strategies. Active Engagement Strategies for Each Explocit Intruction Component. Shasta County Office of Education. [Online] Available: http://www.shastacoe.org/page.cfm?p=3232 (September 30, 2011).

Tateoka, Yoko. (n.d.). Pea raningu [Peer learning]. Japan Foundation (2011). Nihongo Kyouiku Tsuushin. http://www.jpf.go.jp/j/japanese/survey/tsushin/reserch/033.html_

The Japan Foundation Kuala Lumpur. 2010. Malaysian Teachers Struggling with Japanese Language: The Japan Foundation Supports Trainings for Teachers of Secondary Education, August 2010. [Online] Available: http://www.jpf.go.jp/world/en/archives/1008.html (December 12, 2010). 


\section{Appendix}

Appendix: Quantitative Data Items and Analysis according to Types of Activities

SECTION A: Speaking Journal Development

\begin{tabular}{|c|c|c|c|c|c|}
\hline Item & $\begin{array}{l}1 \\
\text { Strongly } \\
\text { Disagree } \\
(\%)\end{array}$ & 2 & 3 & 4 & $\begin{array}{l}5 \\
\text { Strongly } \\
\text { Agree }\end{array}$ \\
\hline I enjoy developing my speaking journal & $\begin{array}{l}0 \\
(0 \%)\end{array}$ & $\begin{array}{l}1 \\
(7 \%)\end{array}$ & $\begin{array}{l}2 \\
(14 \%)\end{array}$ & $\begin{array}{l}9 \\
(64 \%)\end{array}$ & $\begin{array}{l}2 \\
(14 \%)\end{array}$ \\
\hline $\begin{array}{l}\text { It has helped me in self-directed learning as I can } \\
\text { analyze problems on my own. }\end{array}$ & $\begin{array}{l}0 \\
(0 \%)\end{array}$ & $\begin{array}{l}0 \\
(0 \%)\end{array}$ & $\begin{array}{l}1 \\
(7 \%)\end{array}$ & $\begin{array}{l}10 \\
(71 \%)\end{array}$ & $\begin{array}{l}3 \\
(21 \%)\end{array}$ \\
\hline $\begin{array}{l}\text { Developing the speaking journal is a stressful } \\
\text { process. }\end{array}$ & $\begin{array}{l}1 \\
(7 \%)\end{array}$ & $\begin{array}{l}2 \\
(14 \%) \\
\end{array}$ & $\begin{array}{l}9 \\
(64 \%) \\
\end{array}$ & $\begin{array}{l}1 \\
(7 \%) \\
\end{array}$ & $\begin{array}{l}1 \\
(7 \%)\end{array}$ \\
\hline $\begin{array}{l}\text { Developing the speaking journal has helped me to } \\
\text { monitor my learning progress. }\end{array}$ & $\begin{array}{l}0 \\
(0 \%) \\
\end{array}$ & $\begin{array}{l}0 \\
(0 \%) \\
\end{array}$ & $\begin{array}{l}1 \\
(7 \%) \\
\end{array}$ & $\begin{array}{l}7 \\
(50 \%) \\
\end{array}$ & $\begin{array}{l}6 \\
(43 \%) \\
\end{array}$ \\
\hline The speaking journal encourages self-reflection. & $\begin{array}{l}0 \\
(0 \%) \\
\end{array}$ & $\begin{array}{l}0 \\
(0 \%) \\
\end{array}$ & $\begin{array}{l}1 \\
(7 \%)\end{array}$ & $\begin{array}{l}10 \\
(71 \%)\end{array}$ & $\begin{array}{l}3 \\
(21 \%)\end{array}$ \\
\hline $\begin{array}{l}\text { I normally listen and develop the speaking journal } \\
\text { to incorporate the development of my learning . }\end{array}$ & $\begin{array}{l}0 \\
(0 \%) \\
\end{array}$ & $\begin{array}{l}0 \\
(0 \%)\end{array}$ & $\begin{array}{l}5 \\
(36 \%) \\
\end{array}$ & $\begin{array}{l}6 \\
(43 \%) \\
\end{array}$ & $\begin{array}{l}3 \\
(21 \%)\end{array}$ \\
\hline $\begin{array}{l}\text { There is adequate guidance and feedbacks given in } \\
\text { developing the speaking journal. }\end{array}$ & $\begin{array}{l}0 \\
(0 \%)\end{array}$ & $\begin{array}{l}0 \\
(0 \%)\end{array}$ & $\begin{array}{l}1 \\
(7 \%) \\
\end{array}$ & $\begin{array}{l}7 \\
(50 \%) \\
\end{array}$ & $\begin{array}{l}6 \\
(43 \%) \\
\end{array}$ \\
\hline $\begin{array}{l}\text { I use resources other than what was taught in class } \\
\text { to develop the learning points. }\end{array}$ & $\begin{array}{l}0 \\
(0 \%)\end{array}$ & $\begin{array}{l}0 \\
(0 \%) \\
\end{array}$ & $\begin{array}{l}5 \\
(36 \%) \\
\end{array}$ & $\begin{array}{l}6 \\
(43 \%) \\
\end{array}$ & $\begin{array}{l}3 \\
(21 \%) \\
\end{array}$ \\
\hline $\begin{array}{l}\text { Developing the speaking journal has given me an } \\
\text { insight into outcome-based learning. }\end{array}$ & $\begin{array}{l}0 \\
(0 \%)\end{array}$ & $\begin{array}{l}0 \\
(0 \%) \\
\end{array}$ & $\begin{array}{l}1 \\
(7 \%)\end{array}$ & $\begin{array}{l}8 \\
(57 \%) \\
\end{array}$ & $\begin{array}{l}5 \\
(36 \%) \\
\end{array}$ \\
\hline $\begin{array}{l}\text { I can appreciate that my speaking skill has } \\
\text { improved. }\end{array}$ & $\begin{array}{l}0 \\
(0 \%)\end{array}$ & $\begin{array}{l}0 \\
(0 \%)\end{array}$ & $\begin{array}{l}3 \\
(21 \%)\end{array}$ & $\begin{array}{l}5 \\
(36 \%) \\
\end{array}$ & $\begin{array}{l}6 \\
(43 \%)\end{array}$ \\
\hline $\begin{array}{l}\text { The speaking journal and feedbacks provided have } \\
\text { changed the way I think when I encounter } \\
\text { problems in my learning. }\end{array}$ & $\begin{array}{l}0 \\
(0 \%)\end{array}$ & $\begin{array}{l}0 \\
(0 \%)\end{array}$ & $\begin{array}{l}3 \\
(21 \%)\end{array}$ & $\begin{array}{l}6 \\
(43 \%)\end{array}$ & $\begin{array}{l}5 \\
(36 \%)\end{array}$ \\
\hline $\begin{array}{l}\text { The speaking journal development has changed my } \\
\text { approach to learning }\end{array}$ & $\begin{array}{l}0 \\
(0 \%)\end{array}$ & $\begin{array}{l}0 \\
(0 \%)\end{array}$ & $\begin{array}{l}0 \\
(0 \%)\end{array}$ & $\begin{array}{l}7 \\
(50 \%) \\
\end{array}$ & $\begin{array}{l}7 \\
(50 \%) \\
\end{array}$ \\
\hline $\begin{array}{l}\text { Developing the speaking journal has helped me to } \\
\text { monitor the learning goals. }\end{array}$ & $\begin{array}{l}0 \\
(0 \%)\end{array}$ & $\begin{array}{l}0 \\
(0 \%)\end{array}$ & $\begin{array}{l}1 \\
(7 \%)\end{array}$ & $\begin{array}{l}8 \\
(57 \%)\end{array}$ & $\begin{array}{l}5 \\
(36 \%) \\
\end{array}$ \\
\hline $\begin{array}{l}\text { Developing the speaking journal has helped me to } \\
\text { recognize my strength and weakness. }\end{array}$ & $\begin{array}{l}0 \\
(0 \%)\end{array}$ & $\begin{array}{l}0 \\
(0 \%)\end{array}$ & $\begin{array}{l}0 \\
(0 \%)\end{array}$ & $\begin{array}{l}6 \\
(43 \%) \\
\end{array}$ & $\begin{array}{l}8 \\
(57 \%) \\
\end{array}$ \\
\hline $\begin{array}{l}\text { Developing the speaking journal has helped me to } \\
\text { revise my learning. }\end{array}$ & $\begin{array}{l}0 \\
(0 \%)\end{array}$ & $\begin{array}{l}0 \\
(0 \%)\end{array}$ & $\begin{array}{l}0 \\
(0 \%)\end{array}$ & $\begin{array}{l}8 \\
(57 \%)\end{array}$ & $\begin{array}{l}6 \\
(43 \%)\end{array}$ \\
\hline
\end{tabular}


SECTION B: Role Play Video Creation

\begin{tabular}{|c|c|c|c|c|c|}
\hline Item & $\begin{array}{l}1 \\
\text { Strongly } \\
\text { Disagree } \\
(\%)\end{array}$ & 2 & 3 & 4 & $\begin{array}{l}5 \\
\text { Strongly } \\
\text { Agree }\end{array}$ \\
\hline I enjoy creating the role play videos. & $\begin{array}{l}0 \\
(0 \%) \\
\end{array}$ & $\begin{array}{l}1 \\
(7 \%)\end{array}$ & $\begin{array}{l}4 \\
(29 \%) \\
\end{array}$ & $\begin{array}{l}3 \\
(21 \%) \\
\end{array}$ & $\begin{array}{l}6 \\
(43 \%) \\
\end{array}$ \\
\hline $\begin{array}{l}\text { It has helped me in self-directed learning as I can } \\
\text { analyze problems on my own. }\end{array}$ & $\begin{array}{l}0 \\
(0 \%) \\
\end{array}$ & $\begin{array}{l}1 \\
(7 \%)\end{array}$ & $\begin{array}{l}2 \\
(14 \%)\end{array}$ & $\begin{array}{l}6 \\
(43 \%)\end{array}$ & $\begin{array}{l}5 \\
(36 \%)\end{array}$ \\
\hline Creating the role play video is a stressful process. & $\begin{array}{l}2 \\
(14 \%)\end{array}$ & $\begin{array}{l}3 \\
(21 \%)\end{array}$ & $\begin{array}{l}5 \\
(36 \%)\end{array}$ & $\begin{array}{l}3 \\
(21 \%)\end{array}$ & $\begin{array}{l}1 \\
(7 \%)\end{array}$ \\
\hline $\begin{array}{l}\text { Creating the role play videos has helped me to } \\
\text { monitor my learning progress. }\end{array}$ & $\begin{array}{l}0 \\
(0 \%)\end{array}$ & $\begin{array}{l}0 \\
(0 \%)\end{array}$ & $\begin{array}{l}2 \\
(14 \%)\end{array}$ & $\begin{array}{l}10 \\
(71 \%)\end{array}$ & $\begin{array}{l}2 \\
(14 \%)\end{array}$ \\
\hline $\begin{array}{l}\text { The creation of the role play videos encourages } \\
\text { self-reflection. }\end{array}$ & $\begin{array}{l}0 \\
(0 \%)\end{array}$ & $\begin{array}{l}0 \\
(0 \%)\end{array}$ & $\begin{array}{l}1 \\
(7 \%)\end{array}$ & $\begin{array}{l}11 \\
(79 \%)\end{array}$ & $\begin{array}{l}2 \\
(14 \%)\end{array}$ \\
\hline $\begin{array}{l}\text { I normally create the role play videos to } \\
\text { incorporate the development of my learning } \\
\text { without been asked by the instructor. }\end{array}$ & $\begin{array}{l}1 \\
(7 \%)\end{array}$ & $\begin{array}{l}4 \\
(29 \%)\end{array}$ & $\begin{array}{l}6 \\
(43 \%)\end{array}$ & $\begin{array}{l}2 \\
(14 \%)\end{array}$ & $\begin{array}{l}1 \\
(7 \%)\end{array}$ \\
\hline $\begin{array}{l}\text { There is adequate guidance and feedbacks given in } \\
\text { creating the role play videos. }\end{array}$ & $\begin{array}{l}0 \\
(0 \%)\end{array}$ & $\begin{array}{l}0 \\
(0 \%)\end{array}$ & $\begin{array}{l}1 \\
(7 \%)\end{array}$ & $\begin{array}{l}9 \\
(64 \%)\end{array}$ & $\begin{array}{l}4 \\
(29 \%)\end{array}$ \\
\hline $\begin{array}{l}\text { I use resources other than what was taught in class } \\
\text { to develop the learning points. }\end{array}$ & $\begin{array}{l}0 \\
(0 \%) \\
\end{array}$ & $\begin{array}{l}0 \\
(0 \%)\end{array}$ & $\begin{array}{l}5 \\
(36 \%)\end{array}$ & $\begin{array}{l}6 \\
(43 \%)\end{array}$ & $\begin{array}{l}3 \\
(21 \%)\end{array}$ \\
\hline $\begin{array}{l}\text { Creating the role play videos has given me an } \\
\text { insight into outcome-based learning. }\end{array}$ & $\begin{array}{l}0 \\
(0 \%) \\
\end{array}$ & $\begin{array}{l}0 \\
(0 \%)\end{array}$ & $\begin{array}{l}2 \\
(14 \%)\end{array}$ & $\begin{array}{l}10 \\
(71 \%)\end{array}$ & $\begin{array}{l}2 \\
(14 \%)\end{array}$ \\
\hline $\begin{array}{l}\text { I can appreciate that my spoken communication } \\
\text { has improved. }\end{array}$ & $\begin{array}{l}0 \\
(0 \%) \\
\end{array}$ & $\begin{array}{l}0 \\
(0 \%)\end{array}$ & $\begin{array}{l}3 \\
(21 \%)\end{array}$ & $\begin{array}{l}6 \\
(43 \%) \\
\end{array}$ & $\begin{array}{l}5 \\
(36 \%) \\
\end{array}$ \\
\hline $\begin{array}{l}\text { The role play videos and feedbacks provided have } \\
\text { changed the way I think when I encounter } \\
\text { problems in my learning. }\end{array}$ & $\begin{array}{l}0 \\
(0 \%)\end{array}$ & $\begin{array}{l}0 \\
(0 \%)\end{array}$ & $\begin{array}{l}2 \\
(14 \%)\end{array}$ & $\begin{array}{l}10 \\
(71 \%)\end{array}$ & $\begin{array}{l}2 \\
(14 \%)\end{array}$ \\
\hline $\begin{array}{l}\text { The creation of the role play videos has changed } \\
\text { my approach to learning. }\end{array}$ & $\begin{array}{l}0 \\
(0 \%)\end{array}$ & $\begin{array}{l}0 \\
(0 \%)\end{array}$ & $\begin{array}{l}2 \\
(14 \%)\end{array}$ & $\begin{array}{l}9 \\
(64 \%)\end{array}$ & $\begin{array}{l}3 \\
(21 \%)\end{array}$ \\
\hline $\begin{array}{l}\text { Creating the role play videos has helped me to } \\
\text { monitor the learning goals. }\end{array}$ & $\begin{array}{l}0 \\
(0 \%)\end{array}$ & $\begin{array}{l}0 \\
(0 \%)\end{array}$ & $\begin{array}{l}1 \\
(7 \%)\end{array}$ & $\begin{array}{l}12 \\
(86 \%)\end{array}$ & $\begin{array}{l}1 \\
(7 \%)\end{array}$ \\
\hline $\begin{array}{l}\text { Creating the role play videos has helped me to } \\
\text { recognize my strength and weakness. }\end{array}$ & $\begin{array}{l}0 \\
(0 \%) \\
\end{array}$ & $\begin{array}{l}0 \\
(0 \%)\end{array}$ & $\begin{array}{l}0 \\
(0 \%) \\
\end{array}$ & $\begin{array}{l}8 \\
(57 \%) \\
\end{array}$ & $\begin{array}{l}6 \\
(43 \%) \\
\end{array}$ \\
\hline $\begin{array}{l}\text { Creating the role play videos has helped me to } \\
\text { revise my learning. }\end{array}$ & $\begin{array}{l}0 \\
(0 \%) \\
\end{array}$ & $\begin{array}{l}0 \\
(0 \%) \\
\end{array}$ & $\begin{array}{l}1 \\
(7 \%)\end{array}$ & $\begin{array}{l}7 \\
(50 \%) \\
\end{array}$ & $\begin{array}{l}6 \\
(43 \%) \\
\end{array}$ \\
\hline
\end{tabular}


SECTION C: Classroom Activities

\begin{tabular}{|c|c|c|c|c|c|}
\hline Item & $\begin{array}{l}1 \\
\text { Strongly } \\
\text { Disagree } \\
(\%)\end{array}$ & 2 & 3 & 4 & $\begin{array}{l}5 \\
\text { Strongly } \\
\text { Agree }\end{array}$ \\
\hline $\begin{array}{l}\text { I find that the classroom activities engaging and } \\
\text { interactive. }\end{array}$ & $\begin{array}{l}0 \\
(0 \%) \\
\end{array}$ & $\begin{array}{l}0 \\
(0 \%)\end{array}$ & $\begin{array}{l}1 \\
(7 \%)\end{array}$ & $\begin{array}{l}6 \\
(43 \%) \\
\end{array}$ & $\begin{array}{l}7 \\
(50 \%) \\
\end{array}$ \\
\hline I enjoy the classroom activities. & $\begin{array}{l}0 \\
(0 \%)\end{array}$ & $\begin{array}{l}0 \\
(0 \%)\end{array}$ & $\begin{array}{l}1 \\
(7 \%)\end{array}$ & $\begin{array}{l}6 \\
(43 \%)\end{array}$ & $\begin{array}{l}7 \\
(50 \%)\end{array}$ \\
\hline $\begin{array}{l}\text { The classroom activities helped me in developing } \\
\text { basic understanding of } \\
\text { the learning items. }\end{array}$ & $\begin{array}{l}0 \\
(0 \%)\end{array}$ & $\begin{array}{l}0 \\
(0 \%)\end{array}$ & $\begin{array}{l}0 \\
(0 \%)\end{array}$ & $\begin{array}{l}5 \\
(36 \%)\end{array}$ & $\begin{array}{l}9 \\
(64 \%)\end{array}$ \\
\hline $\begin{array}{l}\text { The classroom activities always incorporate peer } \\
\text { learning. }\end{array}$ & $\begin{array}{l}0 \\
(0 \%)\end{array}$ & $\begin{array}{l}0 \\
(0 \%)\end{array}$ & $\begin{array}{l}0 \\
(0 \%)\end{array}$ & $\begin{array}{l}3 \\
(21 \%) \\
\end{array}$ & $\begin{array}{l}11 \\
(79 \%)\end{array}$ \\
\hline $\begin{array}{l}\text { The peer learning activities helped me to learn } \\
\text { better. }\end{array}$ & $\begin{array}{l}0 \\
(0 \%) \\
\end{array}$ & $\begin{array}{l}0 \\
(0 \%)\end{array}$ & $\begin{array}{l}0 \\
(0 \%) \\
\end{array}$ & $\begin{array}{l}3 \\
(21 \%) \\
\end{array}$ & $\begin{array}{l}11 \\
(79 \%)\end{array}$ \\
\hline $\begin{array}{l}\text { The classroom activities helped me to monitor my } \\
\text { learning progress. }\end{array}$ & $\begin{array}{l}0 \\
(0 \%) \\
\end{array}$ & $\begin{array}{l}0 \\
(0 \%)\end{array}$ & $\begin{array}{l}0 \\
(0 \%)\end{array}$ & $\begin{array}{l}5 \\
(36 \%) \\
\end{array}$ & $\begin{array}{l}9 \\
(64 \%) \\
\end{array}$ \\
\hline The classroom activities encouraged self-reflection. & $\begin{array}{l}0 \\
(0 \%)\end{array}$ & $\begin{array}{l}0 \\
(0 \%)\end{array}$ & $\begin{array}{l}0 \\
(0 \%) \\
\end{array}$ & $\begin{array}{l}6 \\
(43 \%) \\
\end{array}$ & $\begin{array}{l}8 \\
(57 \%) \\
\end{array}$ \\
\hline $\begin{array}{l}\text { The classroom activities helped me to incorporate } \\
\text { the development of my learning. }\end{array}$ & $\begin{array}{l}0 \\
(0 \%)\end{array}$ & $\begin{array}{l}0 \\
(0 \%)\end{array}$ & $\begin{array}{l}0 \\
(0 \%)\end{array}$ & $\begin{array}{l}8 \\
(57 \%)\end{array}$ & $\begin{array}{l}6 \\
(43 \%) \\
\end{array}$ \\
\hline $\begin{array}{l}\text { There is adequate guidance and feedbacks given } \\
\text { during the classroom activities }\end{array}$ & $\begin{array}{l}0 \\
(0 \%) \\
\end{array}$ & $\begin{array}{l}0 \\
(0 \%)\end{array}$ & $\begin{array}{l}1 \\
(7 \%) \\
\end{array}$ & $\begin{array}{l}5 \\
(36 \%)\end{array}$ & $\begin{array}{l}8 \\
(57 \%) \\
\end{array}$ \\
\hline $\begin{array}{l}\text { The classroom activities helped me to develop } \\
\text { insights into outcome-based learning. }\end{array}$ & $\begin{array}{l}0 \\
(0 \%)\end{array}$ & $\begin{array}{l}0 \\
(0 \%)\end{array}$ & $\begin{array}{l}2 \\
(14 \%)\end{array}$ & $\begin{array}{l}6 \\
(43 \%)\end{array}$ & $\begin{array}{l}6 \\
(43 \%)\end{array}$ \\
\hline $\begin{array}{l}\text { I can appreciate that my spoken communication has } \\
\text { improved. }\end{array}$ & $\begin{array}{l}0 \\
(0 \%)\end{array}$ & $\begin{array}{l}0 \\
(0 \%)\end{array}$ & $\begin{array}{l}2 \\
(14 \%)\end{array}$ & $\begin{array}{l}8 \\
(57 \%)\end{array}$ & $\begin{array}{l}4 \\
(29 \%)\end{array}$ \\
\hline $\begin{array}{l}\text { The classroom activities helped me to monitor the } \\
\text { learning goals. }\end{array}$ & $\begin{array}{l}0 \\
(0 \%)\end{array}$ & $\begin{array}{l}0 \\
(0 \%)\end{array}$ & $\begin{array}{l}0 \\
(0 \%)\end{array}$ & $\begin{array}{l}9 \\
(64 \%)\end{array}$ & $\begin{array}{l}5 \\
(36 \%)\end{array}$ \\
\hline $\begin{array}{l}\text { The classroom activities helped me to recognize } \\
\text { my strength and weakness. }\end{array}$ & $\begin{array}{l}0 \\
(0 \%)\end{array}$ & $\begin{array}{l}0 \\
(0 \%)\end{array}$ & $\begin{array}{l}0 \\
(0 \%)\end{array}$ & $\begin{array}{l}6 \\
(43 \%)\end{array}$ & $\begin{array}{l}8 \\
(57 \%)\end{array}$ \\
\hline $\begin{array}{l}\text { The classroom activities helped me to revise my } \\
\text { learning. }\end{array}$ & $\begin{array}{l}0 \\
(0 \%)\end{array}$ & $\begin{array}{l}0 \\
(0 \%)\end{array}$ & $\begin{array}{l}2 \\
(14 \%)\end{array}$ & $\begin{array}{l}5 \\
(36 \%) \\
\end{array}$ & \begin{tabular}{|l}
7 \\
$(50 \%)$ \\
\end{tabular} \\
\hline
\end{tabular}

